\title{
CORPORATE IMAGE MANAGEMENT IN MUNICIPAL UTILITY COMPANIES
}

\author{
PuPAVAC, D.; MARSANIC, R. \& BABIC, M.
}

Abstract: The basic objective of this scientific essay is to determine and evaluate the current image of utility companies in the city of Rijeka. In order to attain the objective of the research, a "face to face" questionnaire has been drawn up. The questionnaire studied the identification of utility service providers, the overall satisfaction with how the companies provide these utility services, the satisfaction with particular services and the complaints related to the services provided. The research comprised all the utility services provided in the area of the city of Rijeka. The research on the sample of 500 households stratified by city boroughs was carried out by the "Puls" agency. The respondent is an adult member of the household familiar with the paying process of most of the utility services researched. The obtained information should serve as a point of reference for further continuous research of image, for successful image management and for the selection of adequate strategy in redefining or reinforcing the image of utility companies within the city of Rijeka.

Key words: corporate image, corporate management, municipal utility companies
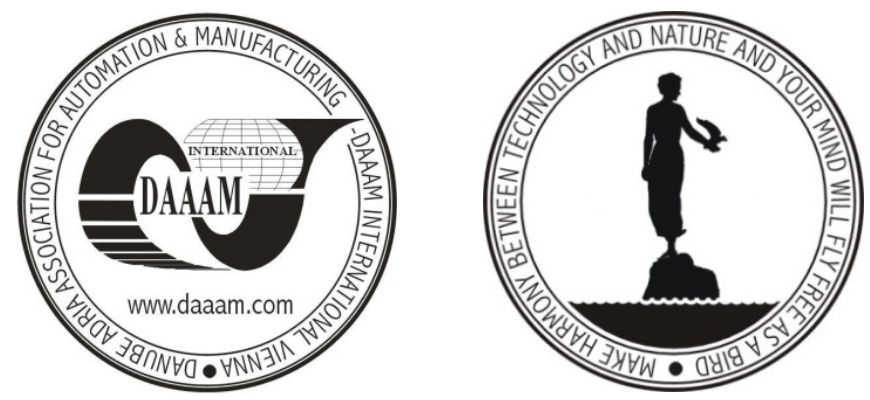

Authors' data: Dr. Sc. Papavac, D[rago]*; Dr. Sc. Marsanic, R[obert]**; Dr. Sc. Babic, M[irjana]***, *Polytehnic of Rijeka, Vukovarska 58, 51000 Rijeka, Croatia, ** Rijeka Promet, d.d. Fiumara 13, 51000 Rijeka, Croatia, *** Autotrolej, d.o.o., Skoljic 15, $51000 \quad$ Rijeka, Croatia, drago.pupavac@veleri.hr, marsanic@rijekapromet.hr, mirjana.babic@ri.t-com.hr

This Publication has to be referred as: Pupavac, $\mathrm{D}[\mathrm{rago}]$; Marsanic, R. \& Babic, M[irjarna] (2009). Corporate Image Management in Municipal Utility Companies, Chapter 74 in DAAAM International Scientific Book 2009, pp. 771-778, B. Katalinic (Ed.), Published by DAAAM International, ISBN 978-3-901509-69-8, ISSN 17269687, Vienna, Austria

DOI: $10.2507 /$ daaam.scibook.2009.74 